\title{
ОСВІТНЯ ДІЯЛЬНІСТЬ
}

DOI: http://doi.org/10.37734/2409-6873-2019-4-15

УДК 378

\section{ПРОБЛЕМИ ПІДГОТОВКИ ФАХІВЦІВ У НАВЧАЛЬНИХ ЗАКЛАДАХ УКРАЇНИ}

\author{
В. М. ГАВВА, кандидат економічних наук, професор; \\ М. А. ГоЛОВАНОВА, кандидат технічних наук, доцент \\ (Національний аерокосмічний університет імені М. Є. Жуковського \\ «Харківський авіаційний інститут»)
}

\begin{abstract}
Анотація. Мета статті полягає в зазначенні проблем підготовки фахівців у закладах вищої освіти України та розробленні напрямів їх вирішення. Статтю присвячено дослідженню проблем, які виникли в Україні під час підготовки здобувачів вищої освіти, та виявленню фракторів, які впливають на освітній простір. Розәлянуто учасників і процеси вищої освіти, їх взаємодію та вплив на розвиток суспільства загалом, запропоновано окремі шляхи та інструменти щодо забезпечення і підвищення якості вищої освіти. Методика дослідження. Вирішення поставлених у статті завдань здійснено за допомогою таких загальнонаукових і спеціальних методів дослідження: аналізу та синтезу, спостереження, систематизації та узагальнення, діалектичного та дидактичного підходів. Результати. Проаналізовано та зазначено напрями підвищення якості підготовки фрахівців у закладах вищої освіти України. Практична значущість результатів дослідження. У статті обірунтовано, що впровадження запропонованих заходів сприятиме покращенню освітнього простору, інтеграції в європейський освітній простір. Основні наукові положення статті можна використовувати у практиці розбудови освітньої діяльності.
\end{abstract}

Ключові слова: вища освіта, заклад вищої освіти, компетентності, освітня діяльність, дисципліна, викладач, здобувач вищої освіти, фрахівець.

Постановка проблеми в загальному вигляді та зв'язок із найважливішими науковими чи практичними завданнями. Україна втрачає свій інноваційний потенціал, i, на жаль, процес цей прогресує. Ще трапляються окремі успіхи, але, зазвичай, вони є наслідком творчого напрацювання 3 минулих часів. Обдарована молодь шукає притулку в інших країнах, у ЗВО працюють старі за віком викладачі, а перспективні випускники не бажають працювати викладачами за оплату на рівні прожиткового мінімуму. Середня освіта стає все «середнішою», бо вчитель або викладач університету сьогодні вже не $\epsilon$ в Україні поважною людиною, судячи 3 рівня оплати його праці. 3ВО змушені розпочинати навчальний процес із ліквідації недоліків шкільної підготовки. Усе це призводить до того, що сьогодні в університетах $є$ брак якості викладання, наукових досліджень і навколишнього середовища для студентів. Тому питання поліпшення якості 
складових освітнього процесу є актуальними й потребують задіяності всіх учасників освітнього процесу.

Аналіз останніх досліджень і публікацій. Питання формування практичної та професійної діяльності випускників закладів вищої освіти, у тому числі й економічної підготовки, є одним із пріоритетних на сучасному етапі розвитку суспільства. Проблеми реформування професійної освіти в Україні досліджуються у працях учених: Є. В. Раевневої, І. В. Аксьонова, С.В.Перегуди, О. В. Полуніна, Н. Г. Батечко, Н. В. Мосьпан, Г. Я. Аніловської, 3. Н. Курлянд, І. М. Козубцова та ін.

Формулювання цілей статті (постановка завдання). Метою статті $є$ зазначення проблем підготовки фахівців у закладах вищої освіти України та розроблення напрямів їх вирішення.

Виклад основного матеріалу дослідження 3 повним обгрунтуванням отриманих наукових результатів. Бурхливе зростання кількості навчальних закладів в Україні протягом останніх десятиліть (на перший погляд, начебто добре) не поліпшує становища 3 освітою і рівнем знань, а, навпаки, погіршує. Комерціалізація освіти й боротьба за грошові потоки в цій сфері послуг відповідним чином знизили вимоги до студентів. Якщо це передати мовою маркетингу, то замість підготовки «товару» високої якості та властивостей заклади освіти розпочали випуск «товарів широкого вжитку» дуже невисокого гатунку. Хто ж працюватиме в наукоємних i високотехнологічних галузях, продовжуючи справу попередніх поколінь фахівців? Ми незабаром втратимо навіть і ті технології, що вже маємо.

Підтримувати високу планку вимог до знань студентів 3ВО сьогодні не є можливим - вони відкинуті у стан виживання, а поточні проблеми 3 оплатою тепла, енергоносіїв тощо заважають 3ВО виконувати державостверджувальну місію - підготовку фахівців високого рівня для підприємств, наукових і проектних установ України. Це важлива державна справа. Тому на підготовку фахівців, особливо для роботи в найважливіших для держави галузях, повинна бути монополія держави. Недержавні заклади освіти мають право на існування, але не для будь-яких спеціальностей і без надання випускникам дипломів державного зразка й певних гарантій.

Узагалі, прийом на роботу підприємствами та установами фахівців-випускників ЗВО повинен відбуватись на конкурсній основі. Це одразу розставить все на своє місце. ЗВО, які не турбують студентів високими вимогами на іспитах i відповідним рівнем викладання, поступово втратять абітурієнтів, оскільки їхніх випускників ніхто не прийматиме на роботу.

У зв'язку із зростаючими обсягами інформації та тенденціями до більш вузької спеціалізації сучасних фахівців, у силу обмеженості можливостей людини щодо засвоювання інформації необхідно ретельно проаналізувати перелік дисциплін в освітніх програмах підготовки фахівців відповідного спрямування в бік збільшення обсягу кредитів окремих фундаментальних i професійних дисциплін і зменшення обсягу, або навіть викреслювання із планів, дисциплін другорядних, які не є вкрай необхідними в подальшій роботі та майже не забезпечують формування компетентностей за відповідним Стандартом та зазначених у відповідній освітній програмі. Їх вивчення має бути особистим надбанням фахівця.

Для підвищення рівня викладання дисциплін потрібно надати можливість студентам 3ВО самим обирати собі провідних викладачів для вивчення відповідної дисципліни. Це дасть змогу формувати індивідуальний план кожного викладача й обсяг його навантаження на навчальний рік не за формальним розподілом навчальної роботи між членами кафедри, а враховуючи вибір студентів. Це також дозволить обгрунтувати переведення викладача на 0,75 або на 0,5 ставки i навіть позбавитися викладачів, послуги яких студентам зовсім не потрібні. Не треба боятися цього шляху. Студенти добре розуміють: хто прийшов їх навчати, а хто відбуває час. Певний досвід таких практик у провідних 3 ВО розвинених країн світу є. Крім того, доцільно було б анонімне анкетування «Викладач очима студента» зробити регулярним та застосовувати не тільки для аналізу, а й для зворотного зв'язку. Результати такого анкетування можна використовувати для вирішення питання матеріального заохочення викладачів до сумлінної праці у вигляді, наприклад, поточної надбавки до посадового окладу, або подальшої співпраці 3ВО 3 викладачем. Такий механізм розробити нескладно.

Сьогодні штатно-окладна оплата праці викладачів 3ВО не відповідає сучасним вимогам i не дає змогу відзначати провідних фахівців кафедр. Внесок, затрати праці й зусилля викладачів різні, а оплата однакова, або навіть порівняно менша. Якщо оплату праці викладача передбачити із двох складових: посадового тарифного окладу (мінімального) й надбавки, яка розраховується, наприклад, на семестр через інтегральну рейтингову оцінку праці викладача в попередньому семестрі, то це дало б можливість урахувати кількість і якість його праці й заохочувати до поліпшення діяльності тих, хто «пасе 
задніх». Інтегральна рейтингова оцінка викладача може розраховуватись: за даними вищезгаданого анкетування студентів, за результатами методичної роботи, наукової роботи зі студентами, виховної роботи тощо. До речі, анкетування одразу виявить тих, хто не гребує хабарництвом.

Не можна забувати і про загальне перевантаження викладачів. Збільшується нормативна кількість студентів на викладача, і це негативне явище потрібно зупинити. Про яку індивідуальну роботу може йтися, коли аудиторне навантаження для отримання посадового окладу відповідно до закону хоч і встановлено на рівні до 600 годин, але реальний час на навчальний процес викладач витрачає значно більший, бо повинен формувати велику кількість різного роду звітів, відомостей, заповнювання форм, які не передбачено ані нормами часу, ані іншими документами? Про яку якісну наукову або методичну роботу може йти мова за такої завантаженості викладачів «генеруванням паперів»? На неї нема ні часу, ні сили. Згадується сентенція радянських часів: «Ми робимо вигляд, що працюємо, а начальство вдає вигляду, що платить за роботу».

Очікування студентів має бути гарантовано якістю їх освіти й відповідати на виклики глобального ринку освіти агресивно. Ще декілька років тому стандарти кваліфікацій вищої освіти були майже цілком директивними, на відміну від нинішніх, які базуються на компетентнісній основі. Забезпечення якості викладання в університетах $є$ тим унікальним надбанням університетів, яке пропонується сьогодні студентам, і яке університети мають можливість або застосувати як дуже ефективний інструмент, або проігнорувати його та втратити, може й на зовсім, можливість відповідати вимогам ринку. Для того щоб забезпечити високу якість освіти, освітній продукт (послуга) повинен бути сконструйований так, щоб переконати студентів $\mathrm{i}$ сформувати надалі задоволеність від отримання певної освітньої послуги, а серед потенційних споживачів - високу її цінність. Такий високий рівень якості може бути надано тільки внутрішньою мотивацією академічної спільноти, певним рівнем викладання та організації освітнього процесу [1].

Освітні програми підготовки фахівців і відповідні їм навчальні плани та робочі програми дисциплін, як уже згадувалось, потребують відповідного аналізу й перегляду. Було б доцільно суттєво скоротити кількість освітніх компонент в освітніх програмах і відповідно в навчальних планах, але збільшити загальну кількість кредитів за тими освітніми компонентами (навчаль- ними дисциплінами), що залишаться. Особливо це стосується суміжних дисциплін, які можна було б безболісно об'єднати в одну, тому що їх розподіл і межі є деякою мірою умовними.

Такий підхід до переліку освітніх компонент в освітніх програмах та навчальних планах підготовки фахівців надасть змогу:

1) більш грунтовно з'ясувати та продемонструвати взаємозв'язки окремих суміжних дисциплін, що сприятиме їх неформальному засвоюванню студентами;

2) зменшити кількість екзаменів і заліків у семестрі, але водночас підвищити вимоги щодо змісту відповідей, рівня знань і вмінь, розширить перелік програмних результатів навчання, які мають отримати здобувачі вищої освіти в разі опанування певного освітнього компонента;

3) у рамках такого об'єднання декількох дисциплін в одному компоненті виконувати більш змістовну курсову роботу або індивідуальне завдання, для яких і буває потрібним залучення певної кількості суміжних дисциплін;

4) застосувати ефективний блоковий контроль, як і викладання дисципліни за тематичними блоками, оскільки збільшення тижневої кількості годин на дисципліну надасть таку можливість.

Це не стосується дисциплін загальноосвітніх, хоча можна й навіть потрібно було б проаналізувати деякі з них.

Переглянемо 3 цих міркувань перелік освітніх компонент, які пропонуються більшістю освітніх програм за спеціальністю 051 Економіка. Здається, можна об'єднати й викладати як одну об'єднану дисципліну з відповідною назвою:

- економічну історію та історію економічних учень;

- політичну економію, мікроекономіку й макроекономіку;

- фінанси, гроші та кредит, фінанси підприємства, інвестування, страхування;

- організацію виробництва й менеджмент;

- економічний аналіз і внутрішній економічний механізм;

- економіку й організацію інноваційної діяльності, проектний аналіз, економічне обгрунтування господарських рішень;

- стратегію підприємства, стратегію управління підприємством, конкурентоспроможність фірми, потенціал підприємства тощо.

Як наслідок, замість 21 вищепереліченої навчальної дисципліни залишається сім, але таких, що дадуть змогу суттєво поліпшити навчальний процес і засвоєння цілеспрямованих знань i вмінь $з$ окремого напряму, потрібного фахівцю. 
Здається, що тут є рація. До речі, такий розподіл впорядкує й орієнтацію викладачів на відповідний блок (цикл) дисциплін, зменшить загальну кількість дисциплін, які кожен викладач сьогодні змушений викладати, поліпшить можливість заміни викладача, який раптово захворів, або можливість об'єднання груп і потоків. Кафедра матиме декілька таких циклів, у рамках яких може проводитись і наукова робота відповідного спрямування, і підготовка дипломних робіт бакалаврів та магістрів.

Між тим така дисципліна, як «Економіка підприємства», що дає назву освітнім програмам у значній кількості 3ВО за спеціальністю 051 Економіка, потребує окремої розмови. Якщо уважно розглянемо перелік тем, рекомендований стандартами минулих часів, який залишили університети й у сучасній змістовній частині робочих програм, то побачимо, що він більш нагадує не «Економіку підприємства», а «Вступ до фаху», де намагаються показати зв'язки між усіма сторонами економічної діяльності й завданнями, які постають перед фахівцем з економіки підприємства у практичній діяльності. Воно начебто непогано. Але скорочення і без того недостатньої кількості кредитів на вивчення цієї дисципліни перетворює процес викладання на якесь «попурі» на економічну тему, якщо намагатися хоча б деякою мірою висвітлити перелічені питання.

Академічна свобода, яку надано ЗВО, дає змогу досить швидко реалізувати вищезапропоновані заходи, але вони не вирішують системної кризи в економіці, науковій діяльності та освіті України.

Для того щоб наука в Україні стала безпосередньо продуктивною силою, потрібно піднімати на відповідний рівень увесь ланцюжок підготовки висококваліфікованих кадрів, починаючи 3 дитячих садків та шкіл і закінчуючи інститутами підвищення кваліфікації, стимулюючи творчу й натхненну роботу працівників цих закладів не тільки морально. Завдання освітян і держави - не тільки дати людині необхідний рівень знань, а й виховати патріотичну творчу особистість. Освічені й винахідливі люди в Україні ще $\epsilon$, i вони мають отримувати пристойну оплату праці, щоб їм не потрібно було шукати долі за кордоном. Немає альтернативи інноваційному шляху розвитку й капіталовкладенням у науку.

Виконуючи вимоги до формування освітнього процесу, деякі ЗВО зменшують обсяги аудиторних годин відповідно до вимог (33-55 \% часу, запланованого на певний освітній компонент) у бік нижньої границі, намагаючись вирішити завдання - досягти 600 годин аудиторного навантаження на викладача, при цьому якби віддаючи перевагу самостійній роботі студентів над навчальними дисциплінами. Так, очна освіта в державі поступово стає заочною. Якість заочної освіти всім відома. Недарма за часів СРСР в деяких галузях, таких, як авіакосмічна техніка, вона була заборонена, бо наслідки дій малоосвічених працівників можуть дуже дорого коштувати. Новомодна дистанційна освіта - це ще одне джерело для поповнення позабюджетних коштів 3ВО. Якісної освіти людина, навчаючись тільки дистанційно, не отримає. Хто ж буде займатися інноваціями, генерувати інноваційні ідеї та винаходи? Але елементи дистанційної освіти в поєднанні з очною в сучасному світі ITтехнологій не те що не можна застосовувати, а вони $\epsilon$ просто необхідними, бо знання здобувач вищої освіти повинен мати можливість отримувати в будь-який час і будь-якого місця, мати доступ до бібліотек університетів світу, а не тільки знаходячись у стінах альма-матер.

Деградація науки й освіти повинна бути зупинена, і зупинена не додатковими постановами $\mathrm{MOH} \mathrm{України} \mathrm{щодо} \mathrm{загальної} \mathrm{кількості} \mathrm{науко-}$ вих статей необхідних викладачеві або їх кількості для захисту чергового наукового ступеня, а відповідним фінансуванням науки та освіти, оскільки саме ці капіталовкладення формують майбутнє держави [2].

Занепокоєність МОН України нинішнім станом справ у системі підготовки кадрів радує, але для істотної зміни негативних тенденцій у цій сфері цього замало, потрібні ефективні системні рішення на загальнодержавному рівні, які зачіпають усі етапи підготовки: дошкільні установи, загальноосвітні школи, навчальні заклади освіти I-IV рівнів акредитації. Зрозуміло, що без законодавчої й урядової підтримки $\mathrm{MOH}$ України нічого зробити не зможе в поліпшенні системи підготовки кадрів. Фраза Л. Гриневич: «Від школи, де накачують знаннями, ми переходимо до школи компетентностей», - звучить поки як гасло і мрія [3]. Результати ЗНО у розрізі населених пунктів показують, що вони тим кращі, чим більшим $є$ населений пункт $[3,4]$. Іншими словами, сільські школи мають найгірші оцінки, школи у великих містах - значно кращі, а найкращі результати показав Київ, тобто шкіл, де «накачують» знаннями, на жаль, дуже мало, і зосередилися вони переважно в Києві. Це підтверджує загальний рейтинг шкіл України за результатами ЗНО 2019 року, де у ТОП-200 потрапили майже третина шкіл м. Київ (62 школи), Харків та Львів (по 17 шкіл), Дніпро (8 шкіл), Луцьк та Одеса (по 7 шкіл) [4]. При цьому 168 шкіл із 200 - це школи, які розташовані в обласних центрах. Якщо детальніше проаналі- 
зувати результати ЗНО протягом декілька років, то можна сказати, що рівень підготовленості абітурієнтів неухильно знижується. Причин цьому явищу багато:

- судячи 3 рівня оплати праці, вчителі перестали бути елітарною частиною суспільства, на яку орієнтувалася колись молодь, бажаючи наслідувати їх приклад. Звідси виникає і певна недовіра до вчителя. «Якщо ти такий розумний, то чому ти такий бідний?» Це ж відноситься і до викладачів ЗВО України. Звідси родом і низька мотивація викладачів до підвищення якості своєї праці;

- знання перестали бути тим фактором, від якого залежить успіх і кар'єра. Сьогодні набагато важливіше наявність у сім'ї матеріальних ресурсів і ділових зв'язків. Зайняти «хлібне місце» можна й без заслуг у навчанні, навіть без диплома (прикладів достатньо);

- наука в Україні практично перестала фінансуватися. Усіх сьогодні цікавить результат, тобто прикладна наука. Але без фундаментальної науки й досліджень немає нових відкриттів і нових технологій, немає нових ідей та інновацій у галузях економіки.

Держава, яка не фінансує науку й освіту, приречена. У неї немає майбутнього. Україна сьогодні реально втрачає свій промисловий потенціал і може втратити ті передові технології, якими вона ще недавно володіла. Дуже наявно, що ряд провідних підприємств країни, наприклад, в аерокосмічній галузі, сьогодні вже не зможуть виконати замовлення на виробництво певної групи товарів, якщо таке раптом надійде. Втрачені кадри, а без наступності, без досвіду й навичок тільки за технологічними картами роботу неможливо виконати. Залишається тільки пишатися минулим і згадувати минулі досягнення.

Слід відроджувати окремі галузі та економіку загалом. Так, без реально діючих підприємств галузі авіабудування говорити про Україну як про авіаційно-космічну державу - видавати бажане за дійсність. Які іноземні студенти приїдуть у країну із промисловістю, економікою і системою освіти, що деградують? Недофінансована вища школа відімре сама собою. Вона i так «дихає на ладан», оскільки для більшості випускників сьогодні немає роботи за фахом. I якщо IT-фахівці мають попит на ринку праці, то інші знаходяться у скоєному глухому куті.

Як уже згадувалось вище, в Україні зросла кількість ЗВО. У 1990 р. в Україні було всього 149 інститутів та університетів, де навчалася 881 тис. студентів, а до 2010 року їх стало 349, де навчалося вже 2139 тис. осіб. I це на тлі загального зниження чисельності населення краї- ни. І ліцензії на надання освітніх послуг у $\mathrm{MOH}$ України цим 200 ЗВО видали. На початок 20172018 навчального року в Україні діяв 282 вищий навчальний заклад III-IV рівня акредитації, кількість студентів, які здобували вищу освіту в цих закладах, становила 1322,3 тис. осіб, але тільки шість університетів України входять до рейтингу QS World University Rankings [5], який щорічно визначає найкращі університети світу, ураховуючи цілий ряд параметрів: Харківський національний університет ім. Каразіна (491), Київський національний університет ім. Шевченка (541-550), Національний технічний університет «Харківський політехнічний інститут» (651-700), Національний технічний університет України «Київський політехнічний інститут імені Ігоря Сікорського» (701-750), Сумський державний університет (701-750), Національний університет «Львівська політехніка» (751-800), при цьому жоден університет України не входить до переліку 400 кращих університетів світу. У Великій Британії, чисельність населення якої приблизно 65 млн осіб, усього 160 університетів, і 84 з них входить до світового рейтингу (до ТОП-400 - 45 університетів) [5]. Дивуватися цьому не доводиться. Обсяг фінансування науки й освіти у Великій Британії більш ніж у сто разів перевищує український.

Диспаритет в оплаті праці в Україні деяких категорій чиновників і викладачів, наприклад, або простих громадян просто жахливий. Відмінності можуть мати місце, але не в сотні разів і навіть не в десятки. Про яку соціальну справедливість тут може йти мова? Звідси випливають і соціальна апатія громадян, і правовий нігілізм. «Революції відбуваються не там, де не вистачає матеріальних благ, а там де вони неправильно i несправедливо розподіляються», - писав Конфуцій ще понад 4,5 тис. років назад. Він абсолютно правий. Замість розвитку економіки та створення робочих місць держава поставила українців в чергу за субсидіями, що по суті своїй є відвертим пограбуванням бюджету країни. Необхідно дати людям можливість працювати та отримувати відповідну справедливу оплату за свою працю. Тоді субсидії не знадобляться, а пенсійний фонд отримає відповідне наповнення.

Стан економіки та бюджету країни не поліпшить перехід до 12-річної середньої освіти. Якщо подивитися статистичні дані про кількість випускників шкіл України по роках без урахування демографічних тенденцій, то навіть скромні оцінки за даними 2016 і 2017 років показують, що збільшення тривалості навчання у школі на два роки призведе до відволікання від творчої праці близько 500 тис. осіб [6]. Це для 
країни пряме недоотримання ВВП, до якого слід додати ще й додаткові витрати бюджету країни на забезпечення навчання школярів протягом ще двох років. Такої «розкоші» Україна собі дозволити не може. Тому в цілому базова середня освіта за прискореною програмою за п'ять років - це правильний шлях, але чотири роки віддавати на початкову освіту - нонсенс. За відповідної організації навчального процесу та сучасних технологій навчання досить трьох років. Тим більше, що дітлахи в 1 клас приходять уже підготовленими й абетку з ними вивчати майже не потрібно. Так ми повертаємося до вже забутої нами восьмирічки $(3+5)$, після якої підлітки мають визначитися 3 вибором подальшого шляху - робітнича професія (через відновлену відповідно до сучасних вимог ринку праці систему підготовки робітників) або профільна старша школа 3 подальшим навчанням у ЗВО (бакалавріат та/або магістратура) для тих, хто виявив здібності до навчання [7].

Висновки із зазначених проблем i перспективи подальших досліджень у поданому напрямі. Отже, проблема 3 підготовкою кадрів існує, іï треба вирішувати, але по-іншому, ураховуючи як економічну доцільність, так і народногосподарські інтереси. Пошук принципово нових форм розвитку освіти відповідно до формування нової парадигми розвитку суспільства повинен грунтуватися на використанні інтелектуального капіталу нашої країни, передбачати нові способи організації й інтеграції в систему єдиного світового освітнього простору та, як наслідок, до єдиного світового господарства. У зв'язку з цим усе більш важливою стає система підготовки кадрів у державі й формування інтелектуального капіталу. Усі перелічені питання і проблеми потребують фахового обговорення $\mathrm{i}$ відповідних фахових рішень на державному рівні. Майбутнє України не може бути неважливим для українців!

\section{СПИСОК ВИКОРИСТАНИХ ДЖЕРЕЛ}

1. Голованова М. А. Удосконалення роботи університетів через самооцінювання на основі принципів CAF / М. А. Голованова // Тези доповіді Першої Міжнар. наук.практ. конф. «Модернізація вищої освіти та забезпечення якості освітньої діяльності» (м. Харків, 31 травня 2019 р.). - Харків : ХДУХТ, 2019. - С. 52-54.

2. Гавва В. М. Підготовка фахівців в світі інноваційного шляху розвитку економіки України / В. М. Гавва // Збірник наукових праць «Вісник національного технічного ун-ту «ХПІ»: Технічний прогрес і ефективність виробництва. - 2003. - Вип. 20. - Том. 1. - С. 214-216.

3. Онищенко О. Лилия Гриневич: «От школы, где накачивают знаниями, мы переходим к школе компетентностей» / О. Онищенко // Зеркало недели. - 2017. - № 32 (328). - C. 11.

4. ТОП-200 шкіл України за результатами ЗНО 2019 року // Освіта.иа [Електронний pecypc]. - Режим доступу: http://ru.osvita. ua/school/ rating/65353/ (дата звернення: 8.10.19). - Назва з екрана.

5. QS World University Rankings [Електронний pecypc]. - Режим доступу: https://www. topuniversities.com/university-rankings/ world-university-rankings/2020 (дата звернення: 01.11.19). - Назва з екрана.

6. Раевнева Е. В. Прогнозирование количества абитуриентов ВУЗов в зависимости от демографических изменений и привлекательности высшего образования / Е. В. Раевнева, И. В. Аксенова // Проблемы экономики. - 2015. - № 3. - С. 322-335.

7. Гавва В. Н. Экономические аспекты системы подготовки кадров в Украине XXI века / В. Н. Гавва // Тези доповіді Міжнародної НТК «Інтегровані комп'ютерні технології в машинобудуванні ІКТМ-2017». - Харків : Нац. аерокосм. ун-т ім. М. С. Жуковського «Харк. авіац. ін-т», 2017. - Том. 3. - C. 206-208.

\section{REFERENCES}

1. Golovanova, M. A. (2019). Udoskonalennia robotyuniversytetivcherezsamootsiniuvannia na osnovi pryntsypiv CAF [Improving the work of universities through self-assessment based on CAF principles]. Tezy dop. Pershoi Mizhnar. Nauk.-prakt. konf. "Modernizatsiia vyshchoi osvity ta zabezpechennia yakosti osvitnoi diialnosti" (Kharkiv, 31 travnia 2019 r.) [Abstracts of the First International Scientific and Practical Conference "Upgrading Higher Education and Quality Assurance in Educational Activities" (Kharkiv, May 31, 2019)], pp. 52-54. Kharkiv: KhDUKhT [in Ukrainian].

2. Gavva, V. M. (2003). Pidhotovka fakhivtsiv $v$ sviti innovatsiinoho shliakhu rozvytku 
ekonomiky Ukrainy [Training of experts in the world of innovative way of development of economy of Ukraine]. Visnyk natsionalnoho tekhnichnoho un-tu "KhPI": Tekhnichnyi prohres i efektyvnist vyrobnytstva - Bulletin of National Technical University Kharkiv Polytechnic Institute: Collected papers. Series: Technical progress and efficiency, (20, Vol. 1), (pp. 214-216). Kharkiv: KhPI [in Ukrainian].

3. Onyshchenko O. (2017). Liliya Grinevich: "Ot shkoly, gde nakachivayut znaniyami, my perekhodim k shkole kompetentnostej" [Lilia Grinevich: "From the school where they pump knowledge, we move on to the school of competencies"]. Zerkalo nedely, 32 (328), p. 11 [in Russian].

4. TOP-200 shkil Ukrainy za rezultatamy ZNO 2019 roku [Top 200 schools in Ukraine according to the results of the 2019 EIT]. Osvita.ua. - URL: http://ru.osvita.ua/school/ rating/65353/ (accessed 8 October 2019).

5. QS World University Rankings. URL: https://www.topuniversities.com/ university- rankings/world-university-rankings/2020 (accessed 01 October 2019).

6. Rayevnyeva, O. V., Aksyonova, I. V. (2015). Prognozirovanie kolichestva abiturientov VUZov $v$ zavisimosti ot demograficheskih izmenenij $i$ privlekatel'nosti vysshego obrazovaniya [Forecasting the Number of Prospective University Applicants Depending on Demographic Changes and Attractiveness of Higher Education]. The problems of economy, 3, (pp. 322-335) [in Russian].

7. Gavva, V. N. (2017). Ekonomicheskie aspekty sistemy podgotovki kadrov v Ukraine $X X I$ veka [Economic aspects of the training system in Ukraine of the XXI century] / Tezy dopovidi Mizhnarodnoi NTK "Intehrovani kompiuterni tekhnolohii v mashynobuduvanni IKTM-2017" [Abstracts of the International STC "Integrated Computer Technologies in ICTM-2017"]. Kharkiv : National Aerospace University «Kharkiv Aviation Institute». Vol. 3. pp. 206-208 [in Russian].

В. Н. Гавва, кандидат экономических наук, профрессор; М. А. Голованова, кандидат технических наук, доцент (Национальный аэрокосмический университет имени Н. Е. Жуковского “Харьковский авиационный институт»). Проблемы подготовки специалистов в учебных заведениях Украины.

Аннотация. Цель статьи заключается в указании проблем подготовки специалистов в учреждениях высшего образования Украины и разработке направлений их решения. Статья посвящена исследованию проблем, которые возникли в Украине при подготовке соискателей высшего образования, и выявлению фракторов, влияющих на образовательное пространство. Рассмотрены участники и процессы высшего образования, их взаимодействие и влияние на развитие общества в целом, предложены отдельные пути и инструменты по обеспечению и повышению качества высшего образования. Методика исследования. Решение поставленных в статье задач осуществлено с помощью таких общенаучных и специальных методов исследования: анализа и синтеза, наблюдения, систематизации и обобщения, диалектического и дидактического подходов. Результаты. Проанализированы и определены направления повышения качества подготовки специалистов в учреждениях высшего образования Украины. Практическая значимость результатов исследования. В статье обосновано, что внедрение предложенных мероприятий будет способствовать улучшению образовательного пространства, интеграции в европейское образовательное пространство. Основные научные положения статьи можно использовать в практике развития образовательной деятельности.

Ключевые слова: высшее образование, учреждение высшего образования, компетентности, образовательная деятельность, дисциплина, преподаватель, соискатель высшего образования, специалист.

V. Gavva, Cand. Econ. Sci., Professor; M. Golovanova, Cand. Techn. Sci., Docent (National Aerospace University "Kharkiv Aviation Institute"). Problems of specialist training in educational establishments of Ukraine.

Annotation. The purpose of the article is to highlight an important and relevant issue for Ukraine - shortcomings in the training of specialists in educational institutions of Ukraine, as well as to analyze 
existing problems with the organization of the educational process and the reasons for the current situation and develop directions for their resolution. The article is devoted to the problems that arose in Ukraine during the preparation of applicants for higher education and the identification of factors affecting the educational environment. The article deals with the participants and the processes of higher education, their interaction and impact on the development of the society as a whole, separate ways and tools to ensure and improve the quality of higher education are proposed. The emphasis is on the fact that science in Ukraine should become directly a productive force, it is necessary to raise the entire chain of training highly qualified personnel to the appropriate level, starting from kindergartens and schools and ending with continuing education institutions, stimulating the creative and inspirational work of the employees of these institutions. Methodology of research. The solution of the tasks posed in the article was carried out using such general scientific and special research methods as analysis and synthesis, observation, systematization and generalization, dialectic and didactic approaches. Findings. The directions for improving the quality of training of specialists in higher educational establishments of Ukraine are analyzed and identified. Practical value. The article substantiates that the implementation of the proposed activities will contribute to the improvement of the educational environment and integration into the European educational environment. Conclusions were drawn about the need to introduce a new education system in Ukraine. The main scientific statements of the article can be used in the practice of educational activities development.

Keywords: higher education, institution of higher education, competencies, educational activities, discipline, teacher, higher education applicant, specialist. 